\title{
Biopolitics in the Time of Coronavirus
}

\author{
Daniele Lorenzini
}

2 April 2020

In a recent blog post, Joshua Clover rightly notices the swift emergence of a new panoply of "genres of the quarantine." It should not come as a surprise that one of them centers on Michel Foucault's notion of biopolitics, asking whether or not it is still appropriate to describe the situation that we are currently experiencing. Neither should it come as a surprise that, in virtually all of the contributions that make use of the concept of biopolitics to address the current coronavirus pandemic, the same bunch of rather vague ideas are mentioned over and over again, while other-no doubt more interesting-Foucauldian insights tend to be ignored. In what follows, I discuss two of these insights, and I conclude with some methodological remarks on the issue of what it may mean to "respond" to the current "crisis."

\section{The "Blackmail" of Biopolitics}

The first point that I would like to make is that Foucault's notion of biopolitics, as he developed it in 1976, was not meant to show us just how evil this "modern" form of power is. ${ }^{2}$ Of course, it was not meant to praise it either. It seems to me that, in coining the notion of biopolitics, Foucault wants first and foremost to make us aware of the historical crossing of a threshold and more specifically of what he calls a society's "seuil de modernité

1. Joshua Clover, "The Rise and Fall of Biopolitics: A Response to Bruno Latour," in "Posts from the Pandemic," an online supplement to Critical Inquiry 47 (Winter 2021): S28.

2. See Michel Foucault, The History of Sexuality, Volume 1: An Introduction, trans. Robert Hurley (New York, 1978), pp. 135-45 and "Society Must Be Defended": Lectures at the Collège de France, 1975-1976, trans. David Macey (New York, 2003), pp. 239-63; hereafter abbreviated "S." 
biologique" ("threshold of biological modernity"). ${ }^{3}$ Our society crossed such a threshold when the biological processes characterizing the life of human beings as a species became a crucial issue for political decision-making, a new "problem" to be addressed by governments—and this, not only in "exceptional" circumstances (such as that of an epidemic), but in "normal" circumstances as well (" $S$," p. 244). A permanent concern that defines what Foucault also calls the "étatisation du biologique" (the "nationalization of the biological”) (“S," p. 240; trans. mod.). To remain faithful to Foucault's idea that power is not good or bad in itself, but that it is always dangerous (if accepted blindly, that is, without ever questioning it), one could say that this "paradigm shift" in the way in which we are governed, with both its positive and its horrible outcomes, no doubt corresponds to a dangerous extension of the domain of intervention of power mechanisms. We are no longer governed only, nor even primarily, as political subjects of law, but also as living beings who, collectively, form a global mass — a "population" — with a natality rate, a mortality rate, a morbidity rate, an average life expectancy, and so on.

In "What is Enlightenment?" Foucault claims that he wants to refuse the "'blackmail' of Enlightenment" - that is, the idea that we have to be either "for" or "against" it - and address it instead as a historical event that still characterizes, at least to a certain extent, what we are today. ${ }^{4}$ I would like to suggest, in an analogous way, that it would be wise for us to refuse the "blackmail" of biopolitics: we do not have to be "for" or "against" it (what would that even mean?), but address it as a historical event that still defines, at least in part, the way in which we are governed, the way in which we think about politics and about ourselves. When, in the newspapers or on social media, I see people complaining about others not respecting the quarantine rules, I always think about how astonishing it is for me, on the contrary, that so many of us are, even when the risk of sanctions, in most situations, is quite low. I also noticed the panoply of quotes from Discipline and Punish, in particular from the beginning of the chapter "Panopticism," which of course

3. Foucault, The History of Sexuality, Volume 1, p. 143; trans. mod.

4. Foucault, "What is Enlightenment," trans. Catherine Porter, in The Foucault Reader, ed. Paul Rabinow (New York, 1984), pp. 42, 43.

DANIELE LORENZINi is assistant professor of philosophy at the University of Warwick, where he is also deputy director of the Centre for Research in PostKantian European Philosophy. A coeditor of Foucault Studies, his most recent books include La force du vrai: De Foucault à Austin (2017) and Éthique et politique de soi: Foucault, Hadot, Cavell et les techniques de l'ordinaire (2015). 
perfectly resonates with our current experience of the quarantine, as it describes the disciplinarization of a city and its inhabitants during a plague epidemic. ${ }^{5}$ However, if we just insist on coercive measures, on being confined, controlled, and "trapped" at home during these extraordinary times, we risk overlooking the fact that disciplinary and biopolitical power mainly functions in an automatic, invisible, and perfectly ordinary way-and that it is most dangerous precisely when we do not notice it.

Instead of worrying about the increase of surveillance mechanisms and indiscriminate control under a new state of exception, I therefore tend to worry about the fact that we already are docile, obedient biopolitical subjects. Biopolitical power is not (only) exercised on our lives from the outside, as it were, but has been a part of what we are, of our historical form of subjectivity, for at least the past two centuries. This is why I doubt that any effective strategy of resistance to its most dangerous aspects should take the form of a global refusal, following the logic of the blackmail of biopolitics. Foucault's remarks about a "critical ontology of ourselves"6 may turn out to be surprisingly helpful here, since it is the very fabric of our being that we should be ready to question.

\section{The (Bio)Politics of Differential Vulnerability}

The second point that I would like to discuss - a crucial one, but alas one that I rarely find mentioned in the contributions mobilizing the notion of biopolitics to address the current coronavirus pandemic - is the inextricable link that Foucault establishes between biopower and racism. In a recent piece, Judith Butler rightly remarks "the rapidity with which radical inequality, nationalism, and capitalist exploitation find ways to reproduce and strengthen themselves within the pandemic zones."7 This comes as a much-needed reminder in a moment in which other thinkers, such as JeanLuc Nancy, argue on the contrary that the coronavirus "puts us on a basis of equality, bringing us together in the need to make a common stand." course, the equality Nancy is talking about is just the equality of the wealthy and the privileged-those who are lucky enough to have a house or an apartment to spend their quarantine in and who do not need to work

5. See “Coronavirus and Philosophers," European Journal of Psychoanalysis, www.journal -psychoanalysis.eu/coronavirus-and-philosophers/. To read Foucault's analysis in full, see Foucault, Discipline and Punish: The Birth of the Prison, trans. Alan Sheridan (New York, 1977), pp. 195-200.

6. Foucault, "What is Enlightenment," p. 47.

7. Judith Butler, "Capitalism Has Its Limits," Verso Books, 30 Mar. 2020, www.versobooks .com/blogs/4603-capitalism-has-its-limits

8. Jean Luc Nancy, “Communovirus," Verso Books, 27 Mar. 2020, www.versobooks.com /blogs/4626-communovirus 
or can work from home, as Bruno Latour already observed. ${ }^{9}$ What about those who are still forced to go to work every day because they cannot work from home nor afford to lose their paycheck? What about those who do not have a roof over their head?

In the last lecture of "Society Must Be Defended," Foucault argues that racism is "a way of introducing a break into the domain of life taken over by power: the break between what must live and what must die" (" $S$," p. 254; trans. mod.). In other words, with the emergence of biopolitics, racism becomes a way of fragmenting the biological continuum - we all are living beings with more or less the same biological needs-in order to create hierarchies between different human groups, and thus (radical) differences in the way in which the latter are exposed to the risk of death. The differential exposure of human beings to health and social risks is, according to Foucault, a salient feature of biopolitical governmentality. Racism, in all of its forms, is the "condition of acceptability" of such a differential exposure of lives in a society in which power is mainly exercised to protect the biological life of the population and enhance its productive capacity (" $S$," p. 255; trans. mod.). We should therefore carefully avoid reducing biopolitics to the famous Foucauldian formula "making live and letting die" ("S," p. 241). ${ }^{10}$ Biopolitics does not really consist in a clear-cut opposition of life and death, but is better understood as an effort to differentially organize the gray area between them. The current government of migration is an excellent example of this, as Martina Tazzioli convincingly shows when talking of "biopolitics through mobility." ${ }^{11}$ Indeed, as we are constantly, sometimes painfully reminded these days, biopolitics is also, and crucially, a matter of governing mobilityand immobility. Maybe this experience, which is new for most of us, will help us realize that the ordinary way in which "borders" are more or less porous for people of different colors, nationalities, and social extractions deserves to be considered as one of the main forms in which power is exercised in our contemporary world.

In short, biopolitics is always a politics of differential vulnerability. Far from being a politics that erases social and racial inequalities by reminding us of our common belonging to the same biological species, it is a politics that structurally relies on the establishment of hierarchies in the value of

9. See Bruno Latour, "Is This a Dress Rehearsal?" in "Posts from the Pandemic," pp. S25-27.

10. See also Foucault, The History of Sexuality, Volume 1, pp. 138-41.

11. Martina Tazzioli, The Making of Migration: Biopolitics of Mobility at Europe's Borders (London, 2019), p. 106. Although this has passed virtually unnoticed, in the first volume of his History of Sexuality, Foucault mentions migrations as one of the main areas in which biopolitical mechanisms of power function. See Foucault, The History of Sexuality, Volume 1, p. 140. 
lives, producing and multiplying vulnerability as a means of governing people. We might want to think about this next time that we collectively applaud the "medical heroes"12 and "care workers"13 who are "fighting the coronavirus." 14 They deserve it, for sure. But are they really the only ones who are "taking care" of us? What about the delivery people who make sure that I receive what I buy while safely remaining in my quarantined apartment? What about the supermarket and pharmacy cashiers, the public-transportation drivers, the factory workers, and all of the other people working (mostly low-income) jobs that are deemed necessary for the functioning of society? Don't they also deserve-and not exclusively under these exceptional circumstances-to be considered "care workers"? The virus does not put us on a basis of equality. On the contrary, it blatantly reveals that our society structurally relies on the incessant production of differential vulnerability and social inequalities.

\section{The Political Grammar of the Crisis}

Foucault's work on biopolitics is more complex, rich, and compelling for us today than what it appears to be under the pen of those who too quickly reduce it to a series of anathemas against disciplinary confinement and mass surveillance or who misleadingly utilize it to talk about the state of exception and bare life. ${ }^{15}$ I do not want to suggest, however, that the notion of biopolitics should be taken as the ultimate explanatory principle capable of telling us what is happening and what the solution to all of our problems is - and this, not only because of the "historically differentiated character of biopolitical phenomena" correctly emphasized by Roberto Esposito, but also for a deeper methodological reason. ${ }^{16}$ Our political thought is a prisoner to the "grammar of the crisis" and its constrained temporality, to the extent that critical responses to the current situation (or, for that matters, to virtually all of the recent economic, social, and humanitarian

12. William Booth, Karla Adam, and Pamela Rolfe, "In Fight against Coronavirus, the World Gives Medical Heroes a Standing Ovation," Washington Post, 26 Mar. 2020, www .washingtonpost.com/world/europe/clap-for-carers/2020/03/26/3do5eb9c-6f66-11ea-a156 -0048b62cdb51_story.html

13. "Clap for Carers: UK in 'Emotional' Tribute to NHS and Care Workers," $B B C$ News, 27 Mar. 2020, www.bbc.com/news/uk-52058013

14. Booth, Adam, and Rolfe, "In Fight against Coronavirus."

15. See Giorgio Agamben's texts on coronavirus at www.quodlibet.it/una-voce-giorgio -agamben, and, for a response, Gordon Hull, "Why We Are Not Bare Life: What's Wrong with Agamben's Thoughts on Coronavirus," New APPS: Art, Politics, Philosophy, Science, 23 Mar. 2020, www.newappsblog.com/2020/03/why-we-are-not-bare-life-whats-wrong-with-agambens -thoughts-on-coronavirus.html

16. Roberto Esposito, "Curati a oltranza," Antinomie, 28 Feb. 2020, antinomie.it/index.php /2020/02/28/curati-a-oltranza/ 
"crises") do not seem able to look beyond the most immediate future. ${ }^{17}$ Thus, if I agree with Latour that the current "health crisis" should "incite us to prepare for climate change," I am far less optimistic than he is: this will not happen unless we replace the crisis-narrative with a long-term critical and creative effort to find multiple, evolving responses to the structural causes of our "crises." 18 To elaborate responses, instead of looking for solutions, would mean to avoid short-term problem-solving strategies aiming at changing as little as possible of our current way of living, producing, traveling, eating, and so on. It would mean exploring alternative social and political paths in the hope that these experiments will last longer than the time between the present crisis and the next one, while acknowledging that these transformations are necessarily slow, as we cannot just get rid of our historical form of being in the blink of an eye. In a word, it would mean having faith in our capacity to build a future, not only for ourselves, but for countless generations yet to come-and to actually start doing it.

17. See Daniele Lorenzini and Martina Tazzioli, "Critique without Ontology: Genealogy, Collective Subjects, and the Deadlocks of Evidence," Radical Philosophy 207 (Spring 2020): 2739.

18. Latour, "Is This a Dress Rehearsal?" p. S25. 